\title{
Museologia e Patrimônio: uma introdução
}

Luiz Carlos Borges

Museu de Astronomia e Ciências Afins

Marcio D'Olne Campos

Universidade Federal do Estado do Rio de Janeiro

Marcio Ferreira Rangel

Museu de Astronomia e Ciências Afins

No mundo contemporâneo, os museus conquistaram uma importante centralidade no panorama político e cultural, deixando de ser lugares meramente de guarda e conservação para se tornarem espaços relacionados com a criação, a comunicação e a produção de conhecimento. De acordo com o Cadastro Nacional de Museus (CNM), atualmente, existem no Brasil mais de 3.000 instituições de diferentes tipologias: arqueologia, história, etnografia, ciência e tecnologia, belas artes, biográficos, museus de sítio, ecomuseus. Esse número está em constante crescimento. Segundo dados obtidos no CNM, somos o país da América Latina com o maior número de museus.

No Brasil, apesar da dimensão continental e do expressivo número de instituições museológicas, até 2003 existiam, em universidades públicas, apenas dois cursos de formação: a Escola de Museologia da Universidade Federal do Estado do Rio de Janeiro (UNIRIO) e a Escola de Museologia da Universidade Federal da Bahia (UFBA). Neste período, sem a mesma dimensão e com algumas interrupções até o seu encerramento, podemos ainda mencionar o curso de museologia da Universidade Estácio de Sá, no Rio de Janeiro. Nos últimos sete anos, esse cenário passou por um importante processo de transformação e ampliação: diversos cursos de graduação foram criados em todas as regiões do país. Devemos também destacar a criação do primeiro Programa de Pós-Graduação em Museologia e Patrimônio (PPG-PMUS) do Brasil, desenvolvido em parceria, mediante um convênio, entre a UNIRIO e o Museu de Astronomia e Ciências Afins/Ministério da Ciência, Tecnologia e Inovação (MAST/MCTI). Implantado em junho de 2006, com o curso de Mestrado e, a partir de 2011, com o de Doutorado, o PPG-PMUS conta, ainda, com o apoio de importantes museus e centros de estudo e defesa do patrimônio, no Brasil e no exterior.

Neste sentido, não é demais ressaltar a importância de publicações consolidadas e com elevado grau de excelência, tal como é o Boletim do Museu Paraense Emílio Goeldi. Ciências Humanas, cujo primeiro número foi lançado em 1894, para a divulgação de pesquisas e seus resultados, e para a inter-relação entre as diversas redes tecnocientíficas, mediante as quais se expressa o seu desenvolvimento.

O presente dossiê Museologia e Patrimônio resulta da iniciativa do Museu Paraense Emílio Goeldi de estimular a organização de números temáticos. O PPG-PMUS reconheceu a relevância de responder afirmativamente a esse desafio. E, nesse sentido, propôs-se a organizar este conjunto de textos relativos a pesquisas sobre museus, museologia e patrimônio. Ressaltamos que a escolha desse tema não se deveu exclusivamente ao fato do PPG-PMUS ser um programa de pós-graduação nessa área do conhecimento, mas principalmente devido à importância que têm, no Brasil, investigações desta natureza. 
Como profissionais diretamente envolvidos com estas discussões, verificamos que ainda há carência de publicações nacionais direcionadas especificamente para esse campo. Para esta proposta temática do Boletim, procuramos autores que pudessem abordar o tema Museologia e Patrimônio de forma interdisciplinar, apresentando diferentes perspectivas teóricas e metodológicas. Desse modo, contamos com a contribuição dos seguintes autores:

Tereza Cristina Scheiner analisa o Museu Integral (ou Museu Total) como questão no campo da Museologia, bem como as diferentes abordagens e os discursos que sobre ele se desenvolvem; partindo da ideia de museu como fenômeno, estabelece as convergências e divergências entre as matrizes teóricas que fundamentam os conceitos de 'museu integral', 'museu comunitário' e 'ecomuseu', assim como as propostas e realizações de uma prática museológica voltada para o social.

Diana Farjalla Correia Lima enfoca o entrelace Museologia-Museu-Patrimônio a partir dos fundamentos da formação do museu, do campo museológico e do patrimônio, destacando os processos de institucionalização de bens culturais, e as significações construídas, ao longo do tempo, que legitimam ações de 'apropriação' por instâncias culturais.

Lúcia Hussak van Velthem aborda o objeto etnográfico e o estudo de coleções etnográficas, transladando sentidos e interpretações que contribuem para a redefinição dessa classe de objetos; discussão a partir da qual, e com objetivos exploratórios, são abordadas as potencialidades do estudo de coleções etnográficas no contexto das redes de troca ameríndias.

Maria Isabel Roque discute os museus de arte e as circunstâncias que determinaram a descontextualização do objeto artístico no espaço museológico, considerando, ainda, um conjunto de procedimentos e ferramentas que recontextualizam os significados do objeto nas suas múltiplas instâncias, contribuindo, dessa forma, para uma redefinição do discurso museológico, mediante o qual o museu passou a compensar as perdas inerentes ao processo de musealização.

Heloisa Helena Fernandes Gonçalves da Costa analisa o surgimento do conceito de 'saúde cultural', suportado pela relação entre museologia, patrimônio e cidadania, uma vez que os museus e monumentos estão inseridos na sociedade civil e seu poder de produzir códigos e valores culturais faz deles parte integrante do processo de promoção das identidades e da cidadania, contribuindo para melhorar a saúde cultural, a autoestima e a qualidade de interação social, elementos indispensáveis à construção de cidades saudáveis.

Marcio Ferreira Rangel problematiza o papel desempenhado por diferentes atores no processo de formação e configuração das áreas da museologia e do patrimônio, enfatizando as convergências e divergências existentes em suas trajetórias, tendo como referencial os diversos projetos e anteprojetos que, desde 1920, buscam normalizá-las.

Marcio D'Olne Campos e Luiz Carlos Borges, ao considerar a exposição "A ciência dos Mebêngôkre: alternativas contra a destruição", versão de 1989, refletem acerca de conceitos relacionados ao consumo de objetos etnográficos e à sua cadeia produtiva, enfatizando alguns aspectos do percurso simbólico desses objetos, desde seu contexto de produção, passando pela musealização, entendida como um balcão metafórico, até sua apropriação por um consumidor (visitante).

Estamos convictos de que esta publicação será de grande interesse para estudantes, professores, pesquisadores e profissionais da Museologia e do Patrimônio, pois se constitui em um quadro no qual estão apontadas diversas tendências teóricas consoantes à pluralidade do debate contemporâneo relativo a essas áreas. 